Available online at www.jmle.org

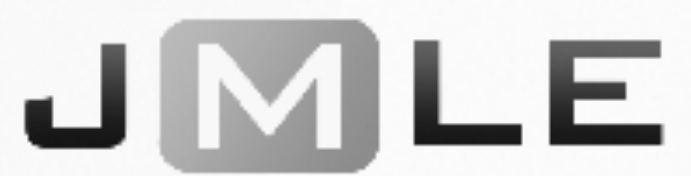

The National Association for Media Literacy Education's

Journal of Media Literacy Education 9 (1), 79 - 98

\title{
News Media Literacy and Political Engagement: What's the Connection?
}

\author{
Seth Ashley \\ Boise State University \\ Adam Maksl \\ Indiana University \\ Stephanie Craft \\ University of Illinois
}

\begin{abstract}
Scholars and educators have long hoped that media education is positively related to prosocial goals such as political and civic engagement. With a focus on measuring news media literacy with emphasis on media knowledge, need for cognition and media locus of control, this study surveyed 537 college students and found positive relationships between news media literacy and two political engagement measures: current events knowledge and internal political efficacy. Findings show that news media literacy is not associated with political activity, although some dimensions of news media literacy are associated with lower levels of political trust. Results help to define significant components of news media literacy and suggest that these components help foster positive relationships with civic and political life.
\end{abstract}

Keywords: news literacy, media literacy, political engagement, civic engagement, media education, survey research

Scholars and educators often assume that media literacy, beyond being a necessary digital-age survival skill, can inspire increased engagement and activity in political and civic life for young learners. As Paul Mihailidis argues in his book Media Literacy and the Emerging Citizen, "media literacy is the path towards more active and robust civic engagement in the $21^{\text {st }}$ century" $(2014,4)$. As the use of digital devices and social networks continues to proliferate, media and digital literacy education "is now fundamentally implicated in the practice of citizenship" (Hobbs 2010a, 16). Proponents of media education have long championed its role in participatory democracy (Masterman 1997). 
At the same time, research supporting the connections between media literacy and improved citizenship remains limited. Some even worry that learning about media can actually nudge students toward disengagement, cynicism, and apathy. This article seeks to address these assumptions and concerns by examining the relationships between media literacy and certain measures of political engagement. Understanding these relationships is vital for educators, scholars and policymakers who want to know how to position media literacy in the broader context of $21^{\text {st }}$ century education and who want to know about possible ways to enhance citizen engagement.

To examine these relationships, this study builds on previous research in media literacy and political and civic engagement. Because these are broad concepts, this study seeks to address these issues through a focus on news by pairing an existing news media literacy survey instrument (Maksl, Ashley, and Craft 2015) with a variety of established measures related to political knowledge, trust, activity and efficacy (Jennings and Zeitner 2003; Pew Research Center 2013; Verba, Schlozman, and Brady 1995).

An increasing amount of scholarly attention is being paid to news media literacy, where an emerging body of work suggests that individuals with higher levels of literacy are better positioned to navigate the endless flow of media messages and to become more engaged, empowered and critical news consumers (Ashley, Maksl, and Craft 2013; Fleming 2014, 2015; Maksl, Ashley, and Craft 2015; Mihailidis 2014; Vraga, Tully, Kotcher, Smithson, and Broeckelman-Post 2015). Interest has ballooned in the growing field of news literacy, particularly as funders such as the Knight and McCormick foundations have begun to support such programs. A 2014 News Literacy Summit, funded by McCormick and organized by the Poynter Institute, brought together a range of interested parties to discuss the field's progress and future. McCormick has also funded a news literacy beat at the Columbia Journalism Review, which has covered the growth of the news literacy movement over the past decade (Beyerstein 2014) as well as the ongoing tensions between different approaches to the subject (Jolly 2014). Part of the debate centers on whether news literacy is a fundamentally new idea and pursuit or if it is simply an extension of a long-standing media education tradition. Even in scholarly circles, researchers continue to debate the meaning, purpose and efficacy of media literacy education broadly (Hobbs 2011; Potter 2010).

Meanwhile, a range of research offers conflicting findings on millennials' interest in news, how and why they consume it, and what they do as a result of having consumed it. There is no question that today's young people (adolescents through traditional college age students) are living large chunks of their lives online and even consuming large amounts of news. A recent Pew survey confirms that millennials are getting most of their news about politics and government from Facebook (Mitchell, Gottfried, and Matsa 2015), even if much of that news exposure is incidental (Mitchell, Kiley, Gottfried, and Guskin 2013) and influenced by algorithms (Dewey 2015). But to what extent is this and other news consumption informed by the critical thinking skills embedded in news media literacy, and what are the effects of having higher levels of news media literacy 
when it comes to knowledge of current events, political activity, trust in politics, and political efficacy? This study seeks to address these questions.

\section{News Media Literacy}

\section{Literature Review}

News media literacy takes the broad goals of media literacy - the ability to access, analyze, evaluate, and create media (Aufderheide and Firestone 1993; NAMLE 2007) - and applies them to news content specifically with a focus on the contexts of news production. With a focus on adolescents and young adults, news literacy scholars and practitioners argue for the importance of critical thinking skills linked to habits of news consumption in order to generate informed citizenship (Fleming 2013; Mihailidis 2014; Poindexter 2012). Scholars argue that news media literacy plays an important role in democratic self-governance, especially when informed by the empirical findings of existing scholarship on the limitations of news media (Ashley, Maksl, and Craft 2013). The topic has even begun to spill over to investigations of audiences in non-democratic regimes (Toepfl 2014).

A range of scholars has begun to write about news media literacy as they attempt to establish common definitions and assessment techniques (Ashley et al. 2013; Fleming 2014; Hobbs 2010a, 2010b; Mihailidis 2014; Vraga et al. 2015). A small number of studies have sought to examine the effects of educational interventions related to news media and have found mixed results. Ashley, Poepsel, and Willis (2010) found that learning about media ownership issues promotes modest increases in critical responses to news media. On the other hand, Vraga, Tully, Akin, and Rojas (2012) found that exposure to a media literacy video led to increased trust and perceptions of news credibility. Vraga, Tully, and Rojas (2009) saw a reduction in perceptions of news bias following media literacy training. A media literacy public service announcement affected conservatives' perceptions of a news host but not liberals' perceptions (Vraga and Tully 2015). Finally, a meta-analysis by Jeong, Cho, and Hwang (2012) lacked a focus on news but found that media literacy educational interventions are often successful and have positive effects on media knowledge, criticism, perceived realism, influence, behavioral beliefs, attitudes, self-efficacy, and behavior. While the effects of news and media literacy education are not clear, studies of this sort generally report some kind of relationship between educational interventions and attitude or behavior change. This common linkage suggests the likelihood of a similar relationship between news media literacy and political engagement.

One avenue of research in news media literacy (Maksl et al. 2015) has relied on an operationalization of Potter's cognitive theory of media literacy (2004). Focusing on the perception, selection, and interpretation of media messages, Potter's cognitive model centers on individuals' media-related knowledge structures, motivations to consume media, and intellectual needs and abilities. Potter identifies five domains - media content, media industries, media effects, the real world, and the self-which, taken together, guide information processing and meaning construction. According to Potter, "With knowledge in these five areas, people are much more aware during the information-processing 
tasks and are, therefore, more able to make better decisions about seeking out information, working with that information, and constructing meaning from it that will be useful to serve their own goals" $(2004,69)$.

Potter's theoretical approach was operationalized by Maksl, Ashley, and Craft (2015), who created a News Media Literacy scale, which consists of three subscales. "Media Knowledge Structures" contains a set of knowledge items related to news media industries, content and effects. "Need for Cognition" and "Media Locus of Control" represent the motivations and needs components of Potter's model. The NML scale has been validated in studies involving high school students (Maksl et al. 2015) and college students (Maksl, Craft, Ashley, and Miller 2016). The scale has been used to group high-literacy and low-literacy individuals, and it has been used in studies showing that higher levels of literacy are associated with greater current events knowledge, greater intrinsic motivations for news consumption, and higher levels of skepticism toward news (Maksl et al. 2015; Maksl et al. 2016).

While no measure is perfect, the NML scale shows promise. As Fleming (2015) notes, the scale is important because it is "among the first empirically sound and statistically significant attempts to define and measure NML knowledge" (77). Fleming also points out that our research team has taken different approaches to measuring NML in various studies, and has not considered the role of instructional pedagogy in forming NML knowledge and skills. Nonetheless, we view the scale as a good starting point for measuring NML and for examining relationships between literacy and various forms of political engagement.

\section{Media and Political Engagement}

Media education has long been associated with pro-social goals related to civic and political engagement. Len Masterman, who is considered a forefather of media literacy, suggested that media education will help lead to improved citizenship and social change. In "A Rationale for Media Education," he writes:

The democratization of institutions, and the long march toward a truly participatory democracy, will be highly dependent upon the ability of majorities of citizens to take control, become effective change agents, make rational decisions (often on the basis of media evidence) and to communicate effectively perhaps through an active involvement with the media $(1997,60)$.

More recently, Mihailidis and Benjamin (2013) note that Masterman's position is just as relevant today, if not more so: "Present-day discussions on the tenets of citizenship cannot avoid including the role of media in civic participation and engagement" (1611). These authors argue for media literacy as a core competency for engaged citizenship in participatory democracy, with a focus on three outcomes for media literate citizens: critical thinkers, creators and communicators, and agents of social change. 
Tension has long been evident among media literacy scholars about the role of political and social contexts in media education (see Hobbs 1998; Kellner and Share 2005; Lewis and Jhally 1998), but it is increasingly clear that in a digitally networked society, political and civic life is an unavoidable topic. As the National Association for Media Literacy Education notes on its "Media Literacy Defined" webpage, "Being literate in a media age requires critical thinking skills that empower us as we make decisions, whether in the classroom, the living room, the workplace, the boardroom, or the voting booth" (NAMLE 2015). Hobbs, Donnelly, Friesem, and Moen (2013) note that students with positive but nuanced views of journalism and society tend to display the highest levels of media literacy; these researchers found "a robust correlation between active participation in video production experience, media literacy, positive attitudes about the news, and civic engagement" (244). Similarly, Mihailidis (2014) concludes that media literacy "is a path for emerging citizens to thrive in a digital culture-leading an active, engaged, and participatory generation" (159). Overall, the foregoing mixture of normative goals and empirical findings leads us to the following hypotheses:

H1: Respondents with higher scores on the news media literacy measure will also be more knowledgeable about current events relative to less news media literate respondents.

H2: Respondents with higher scores on the news media literacy measure will be more politically active relative to less news media literate respondents.

\section{Political Activity, Trust and Efficacy}

While political knowledge may not be a sufficient condition for civic engagement, it is a necessary one (Dudley and Gitelson 2002). A large body of research, mostly in the domain of political communication, has emphasized the importance of a range of variables related to political and civic engagement (see Delli Carpini and Keeter 1996; Eveland and Scheufele 2000). This research has sought to highlight the effects of media and other factors on specific dependent variables including political knowledge, participation, activity, trust and efficacy. Because of growing concern over the decline of political engagement by young people, recent research has placed extra emphasis on how young people rate on such measures (see Kahne, Lee, and Feezel 2012). Political knowledge, activity and trust are commonly linked to media use, but a definitively causal relationship remains difficult to demonstrate (Eveland, Hayes, Shah, and Kwak 2005). This leads us to ask the following research question:

RQ1: What is the relationship between news media literacy scores and respondents' trust in politics?

Researchers also focus on political efficacy, both internal and external, as variables that can be influenced by media use. Political efficacy has been defined 
as "the feeling that individual political action does have, or can have, an impact upon the political process" (Campbell, Gurin, and Miller 1954, 187) and "the belief that one has the skills to influence the political system" (Zimmerman 1989, 554). Internal political efficacy is the idea that an individual is able to create such influence, and external political efficacy is the perceived degree to which the political system will be receptive to an individual's influence. In one attempt to examine these concepts, Baumgartner and Morris (2006) examined the effect of The Daily Show on a variety of political participation variables and found a correlation between Daily Show viewing and increased internal political efficacy. Similarly, other studies have found significant positive relationships between online news use, civic and political participation, and internal political efficacy (Chan 2014; Hoffman and Thompson 2009; Jordan, Pope, Wallis, and Iyer 2014). This kind of internal efficacy is important because even minor increases in reported efficacy can have major effects on political participation such as voting (Moeller, de Vreese, Esser, and Kunz 2014). Active participation in the process of communicating political information online also has a strong impact on internal efficacy (Moeller, de Vreese, Esser and Kunz 2014). Studies of media use often focus on internal political efficacy because it is considered more likely to be a product of communication than external political efficacy (Jung, Kim and Gil de Zuniga 2011). External political efficacy is more likely to be linked with active involvement in public affairs (Zhou and Pinkleton 2012). This literature leads us to ask:

RQ2a: What is the relationship between news media literacy scores and respondents' internal political efficacy?

RQ2b: What is the relationship between news media literacy scores and respondents' external political efficacy?

\section{Method}

We conducted a web survey of students at a large East Coast university in the spring of 2014. After receiving IRB approval, a random sample of 4,000 undergraduate students was sent an email message and two reminders to take the survey, of which 748 responded. After eliminating 211 incomplete responses, 537 responses remained upon which analyses were performed. More respondents were upperclassmen (juniors, 32\%; seniors, 32\%) than underclassmen (freshmen, $15.4 \%$; sophomores, $20 \%)$. Slightly more female $(54.1 \%)$ than male $(45.9 \%)$ students responded. About $7 \%$ of respondents were international students. Slightly fewer than half of the respondents were white (48\%), and nearly onethird (31.2\%) were Asian/Pacific Islanders. African-American students made up $4.6 \%$ of respondents, Latino/Hispanic respondents 6.9\%, Native American respondents $0.4 \%$, multiracial students $6.5 \%$, and those who indicated another category $2.4 \%$. Students were from more than 50 academic majors. More than $90 \%$ of students were traditional-aged college students, between 18 and 24 years old $(\mathrm{M}=21.10, \mathrm{SD}=3.96)$. More than $60 \%$ of students had a parent with at least a bachelor's degree, with $29.2 \%$ with at least one parent with a graduate degree. 


\section{Independent Measures}

Our hypotheses and research questions focus on analyzing differences between those who are highly news media literate and those who are less news media literate. We measured levels of news media literacy by using Maksl, Ashley, and Craft's (2015) News Media Literacy (NML) scale, a multidimensional construct based on Potter's cognitive model of media literacy (2004). Independent measures included measures of media knowledge, need for cognition, and media locus of control.

The first dimension, Media Knowledge Structures, measures knowledge about the institutions that produce news, the way in which the content of the news is produced, and the awareness of possible effects of that content on people. For this dimension, Maksl et al. created fifteen multiple-choice questions, each with a correct answer. For example, questions asked whether respondents knew that most American news media are for-profit businesses, that political campaigns tend to be covered like horse races instead of focusing on in-depth issues about candidates, and that people who watch more television news tend to think the world is more violent than it really is. An index was computed by summing the number of correct answers for each respondent.

The second dimension, Need for Cognition (NOC), was measured using a five-item scale $(\alpha=.745)$ used in previous research (Epstein, Pacini, Denes-Raj, and Heier 1996). Items included "I prefer complex to simple problems" and "I don't like to have to do a lot of thinking." Respondents were asked to respond to each of the statements by saying how much they agreed with it on a five-point scale ( $1=$ strongly disagree; $5=$ strongly agree). Some items were reverse-coded so that a higher score indicated greater mindful thought processing. A mean was computed to develop an overall score.

The third dimension, Media Locus of Control (MLOC), is the degree to which one perceives herself as being in control of whether and how news media influence her. Maksl et al. adapted a scale previously used to measure the extent to which an individual feels they are in control of their own health (Wallston, Wallston, and DeVellis 1978). This led to a six-item scale $(\alpha=.608)$ where respondents were asked their level of agreement with items like "I am in control of the information I get from the news media" and "If I pay attention to different sources of news, I can avoid being misinformed." A higher score indicated a more internal media locus of control. A mean was computed to develop an overall MLOC score.

\section{Dependent Measures}

Dependent measures included current events knowledge, political activity, political trust and political efficacy.

Current events knowledge was measured by asking a series of seven current events questions, adapted from the then-current Pew Research Center's (2013) News IQ Quiz. Items included, for example, identifying a photo of Edward Snowden, knowing who the typical swing vote was on the Supreme Court, knowing what the term "common core" referred to, and knowing what Google 
Glass was. Respondents were presented with multiple-choice questions, and items were dummy-coded into correct or incorrect. The total number of correct answers for each respondent was recorded as an overall current events knowledge score. Appendix A displays these items.

Political activity was measured by presenting respondents with a list of eight activities and asking if they had engaged in each activity. Activities included voting, volunteering for a political candidate, contacting a government official, or contributing money to or volunteering for a political organization. This measure was adapted from Verba, Schlozman, and Brady (1995). Items were dummycoded as yes (1) or no (0), and an index was created by summing the eight items. The higher the score on this index, the more political activities a respondent engaged in. Appendix B displays these items.

Political trust was measured by using a scale that has been used on the National Election Survey (Jennings and Zeitner 2003). Respondents were presented with five statements and asked to indicate their levels of agreement ( $\alpha$ $=.662$ ). Statements included, for example, whether people running the government are dishonest, whether trust can be placed in those in Washington to do the right thing, and whether the government is run by people who know what they are doing. Items were coded so that a higher score indicated a higher level of trust. A mean was computed to develop an overall political trust score.

To measure political efficacy, we used two well-known measures that have been used on the National Election Survey (Jennings and Zeitner 2003). Two statements were used to measure each construct. Internal political efficacy refers to the idea that a person has a sense that he or she has the ability to understand and participate in political activity. Internal political efficacy was measured with the statements "Voting is the only way people like me can have any say about how the government runs things" and "Sometimes politics and government seem so complicated that a person like me can't really understand what's going on" $(\alpha=.464)$. External political efficacy refers to a person's trust in the government being responsive to political demands. External political efficacy was measured with the statements "I don't think public officials care much what people like me think" and "People like me don't have any say about what the government does" $(\alpha=.654)$. Items were coded so that a higher score indicated a higher level of efficacy. Mean scores were computed to develop overall political efficacy scores for each construct. Appendix C displays these items.

Finally, analyses included demographic statistical controls, including age, gender, and parental education. The latter was asked as a proxy for socioeconomic status. Students were asked to respond with the highest level of education at least one of their parents received. We also asked a single question about interest in public affairs (Jennings and Zeitner 2003), which we used as a control.

\section{Results}

The first hypothesis posited that higher news media literate scores would be related to greater knowledge about current events. A hierarchical linear regression analysis was performed, with all three NML dimensions loaded into the same block. Adding in the NML block explained $13.7 \%$ of the variance in 
current events knowledge, and the change in $\mathrm{R}^{2}$ was significant $(F(1,495)=$ $33.20, p<.001)$. However, as Table 1 shows, only the Media Knowledge Structures component of the NML measure was a significant predictor of current events knowledge. Therefore, H1 was partially supported.

Table 1

Hierarchical regression predicting current events knowledge. $(N=537)$

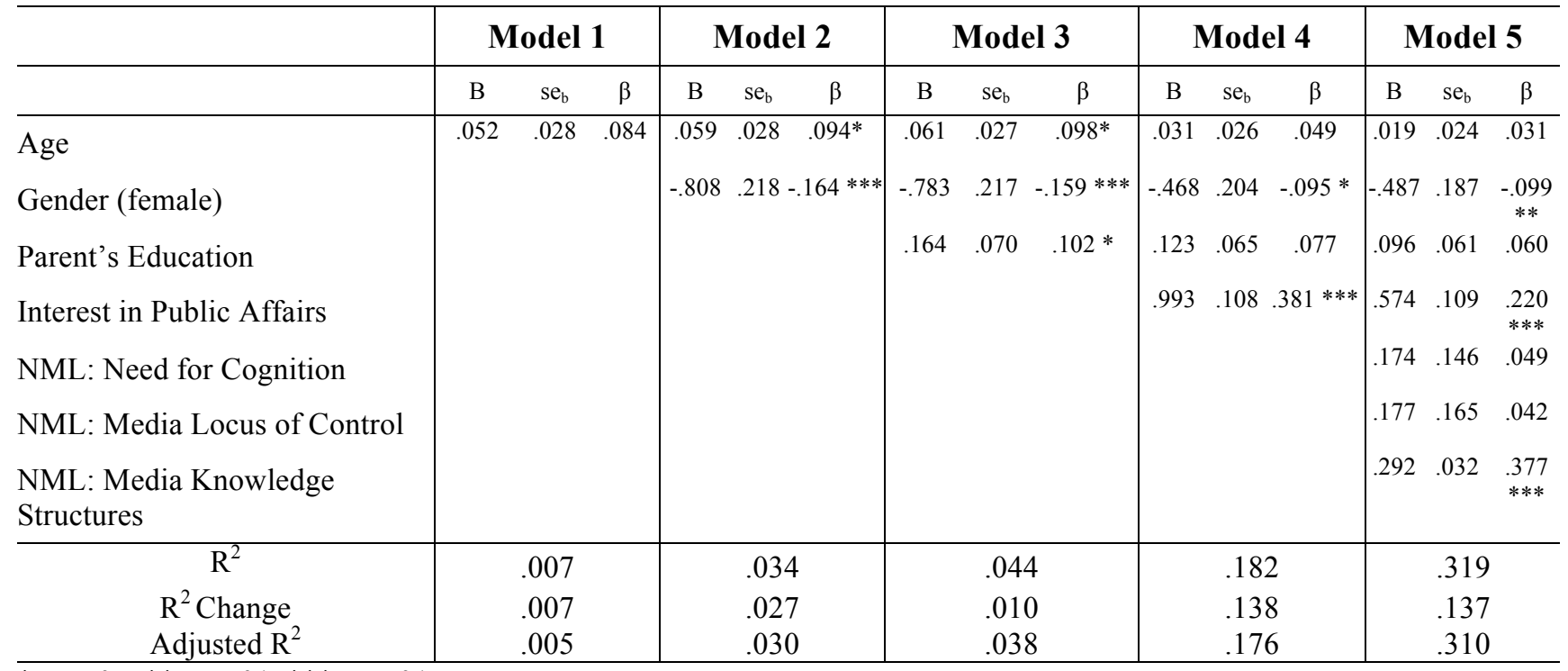

$* p<.05, * * p<.01, * * * p<.01$

The second hypothesis posited that news media literacy scores would be positively related to political activity. When controlling for demographics and political interest, adding the NML block did not explain any significant variance in political activity. Additionally, none of the individual components of the NML measure were statistically significant predictors of political activity. Therefore, $\mathrm{H} 2$ was not supported. However, it should be noted that political activity as a whole was very low for this group of respondents $(\mathrm{M}=1.15, \mathrm{SD}=1.43)$. In fact, $40.9 \%$ of respondents reported no political activity and an additional $32.2 \%$ reported only one activity.

The first research question asked whether news media literacy scores would be related to trust in politics. Hierarchical linear regression analyses showed that adding in the NML block of variables accounted for $10.8 \%$ of the variance in political trust, and the change in $\mathrm{R}^{2}$ was significant $(F(1,495)=20.61$, $p<.001)$. Two of the three dimensions of the NML measure - Need for Cognition and Media Knowledge Structures - were significant predictors of political trust, with higher NML scores related to lower levels of political trust. Media Locus of Control was not a significant predictor of political trust (See Table 3).

The final two research questions asked if news media literacy would be related to levels of political efficacy. With regard to internal political efficacy, the NML block predicted $6.4 \%$ of the variance, and the change in $\mathrm{R}^{2}$ was significant $(F(1,494)=12.83, p<.001)$. Only the Need for Cognition dimension of the NML 
measure was a significant predictor (See Table 4). In this case, higher NFC scores related to feeling more able to understand and participate in the political process. For external political efficacy, the NML block did not add any significant additional explanation of the variance

Table 2

Hierarchical regression predicting political activity. $(N=537)$

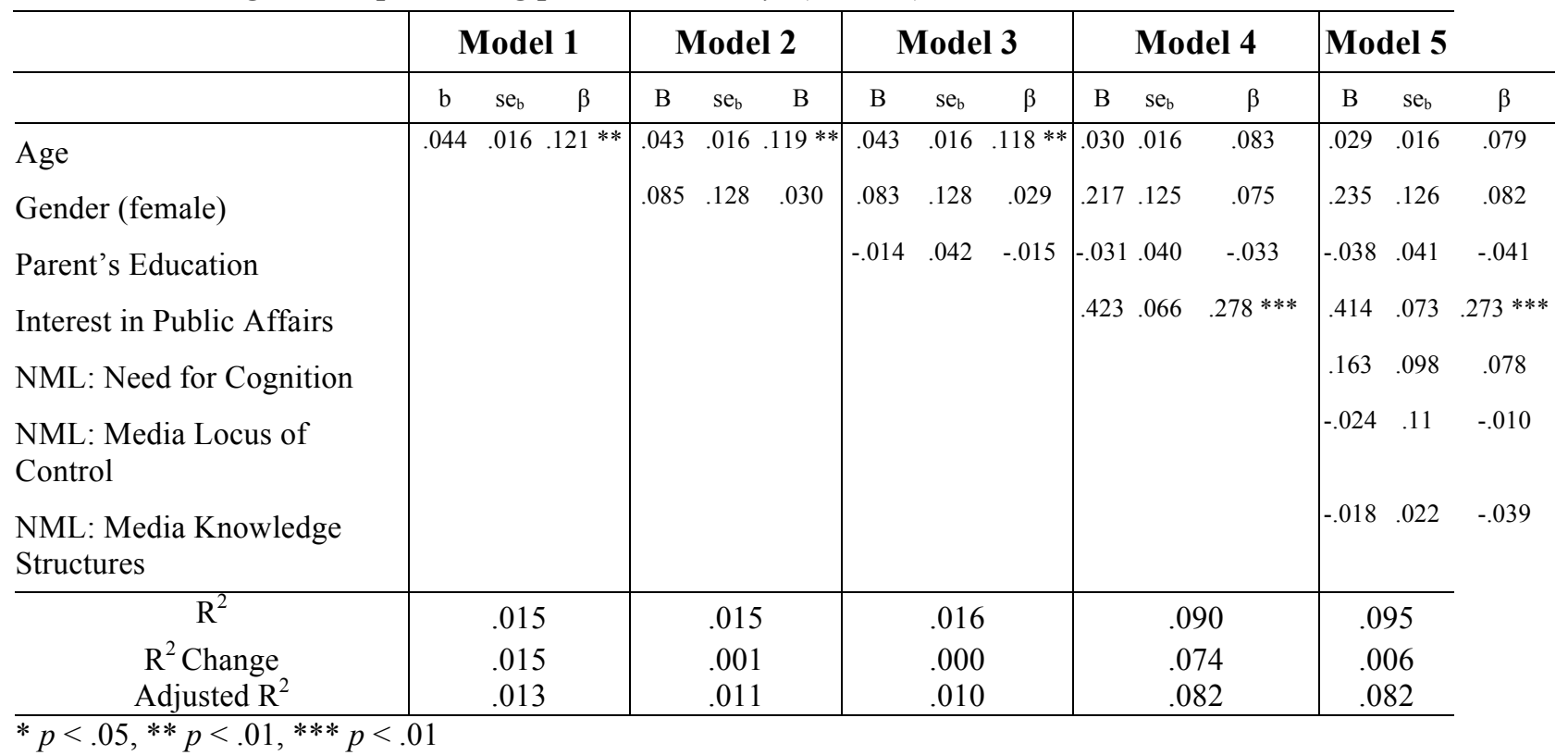

Table 3

Hierarchical regression predicting political trust. $(N=537)$

\begin{tabular}{|c|c|c|c|c|c|c|c|c|c|c|c|c|c|c|}
\hline & \multicolumn{2}{|c|}{ Model 1} & \multicolumn{3}{|c|}{ Model 2} & \multicolumn{3}{|c|}{ Model 3} & \multicolumn{3}{|c|}{ Model 4} & \multicolumn{3}{|c|}{ Model 5} \\
\hline & $\mathrm{b}$ & $\mathrm{se}_{\mathrm{b}}$ & B & $\mathrm{se}_{\mathrm{b}}$ & B & B & $\mathrm{se}_{\mathrm{b}}$ & $\beta$ & B & $\mathrm{se}_{\mathrm{b}}$ & $\beta$ & B & $\mathrm{se}_{\mathrm{b}}$ & $\beta$ \\
\hline Age & -.022 & $.007-.131 *$ & -.022 & .007 & $\begin{array}{c}-.133 \\
* *\end{array}$ & -.022 & .007 & $.133 * *$ & -.020 & .007 & $-.122 * *$ & -.017 & .007 & -.102 \\
\hline Gender (female) & & & .046 & .058 & .036 & .045 & .058 & .035 & .026 & .059 & .020 & .026 & .056 & .020 \\
\hline Parent's Education & & & & & & -.007 & .019 & -.016 & -.004. & .019 & -.010 & .005 & .018 & .013 \\
\hline Interest in Public Affairs & & & & & & & & & -.061. & .031 & -.089 & .041 & .032 & .059 \\
\hline NML: Need for Cognition & & & & & & & & & & & & -.099 & & $-.104 * *$ \\
\hline NML: Media Locus of Control & & & & & & & & & & & & -.018 & .049 & -.016 \\
\hline $\begin{array}{l}\text { NML: Media Knowledge } \\
\text { Structures }\end{array}$ & & & & & & & & & & & & -.064 & .010 & $-.313 * * *$ \\
\hline $\mathrm{R}^{2}$ & & .017 & & .018 & & & .019 & & & .02 & & .1 & & \\
\hline $\mathrm{R}^{2}$ Change & & .017 & & .001 & & & .000 & & & .00 & & .1 & & \\
\hline Adjusted $\mathrm{R}^{2}$ & & .015 & & .014 & & & .013 & & & .01 & & & & \\
\hline
\end{tabular}


Table 4

Hierarchical regression predicting internal political efficacy. $(N=537)$

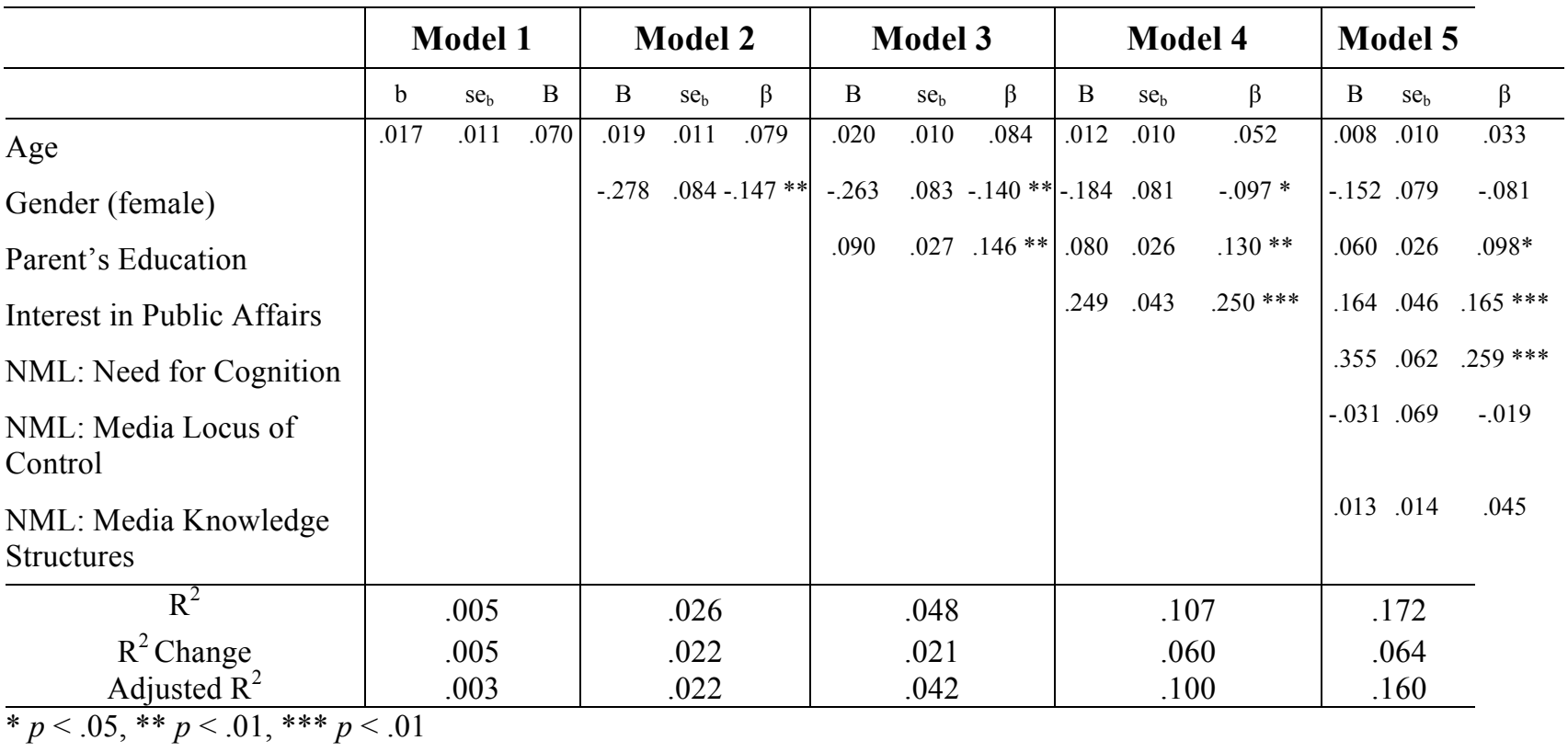

\section{Discussion}

This study confirms the important relationship between certain components of news media literacy and certain types of political engagement, and it offers some support for the widespread adoption of news and media literacy education as a practical component of democratic citizenship. Even when controlling for interest in public affairs, higher levels of news media literacy relate to higher current events knowledge $(\mathrm{H} 1)$, lower trust in politics (RQ1), and higher levels of internal political efficacy (RQ2a). The existence of these relationships is consistent with previous research and thinking, and provides support for the idea that media education can enhance political and civic engagement.

However, though the NML model increased variance explained in these dependent variables, only certain NML dimensions were significant predictors. Based on previous research (Maksl, Ashley, and Craft 2015; Potter 2004), news media literacy consists of Media Knowledge Structures, or knowledge about the American media system's structure, content and effects; Need for Cognition, or having mindful and active habits of thought; and a Media Locus of Control, or a feeling of being in control of one's information environment. Only the Media Knowledge Structures and Need for Cognition components were significant predictors.

Media Knowledge Structures was positively related to knowledge about current events, suggesting that greater knowledge of the media system means that those who better understand the economic and regulatory structure and routines of 
news media are more able to separate the wheat from the chaff and learn about truthful current events. Media Knowledge Structures was negatively related to trust in politics, suggesting that possessing such knowledge about news media makes one less likely to have a favorable view of politics. Perhaps it is unsurprising that media literate individuals have lower trust in the political system considering the often ugly, divisive realities of American politics.

Need for Cognition was positively related to internal political efficacy, suggesting a connection between more mindful processing of media and one's confidence in her ability to be politically engaged. Need for Cognition, along with Media Knowledge Structures, was negatively related to trust in politics, suggesting that mindful and engaged processing of information is connected to a negative or more skeptical view of politics. Again, it is perhaps unsurprising that engaged thinking leads to decreased trust when it comes to American politics.

We found no relationship between the NML subscales and political activity, but respondents reported little political activity overall. That may be an artifact of the political activity measure, which may not be as relevant to college students who may engage in politics and civic life in ways not captured by the index. We also found no relationship between NML and external political efficacy. It is perhaps unsurprising that while internal efficacy was significantly predicted by one NML component, external was not. Media use is related mostly to internal efficacy, according to previous research (Jung, Kim, and Gil de Zuniga 2011; Zhou and Pinkleton 2012). If anything, we might actually expect external political efficacy to show a relationship similar to feelings of political trust, which decline with higher literacy. Finally, the Media Locus of Control component of NML was never a significant predictor, suggesting a flaw in this measure or perhaps pointing out that personal attitudes about one's media consumption are not a meaningful component of news media literacy. Rather, structural knowledge and mindful thinking seem to be the key components.

Based on the significant relationships we did find, we have identified a news media literacy gap, much like a knowledge gap or a digital divide. Several of our dependent variables show that an individual's level of news media literacy does indeed relate to how he or she experiences political and civic life. Like other socio-economic disparities in American society, this media education gap has significant implications for who is more likely to be knowledgeable about and engaged in civic and political life. This is all the more reason that media literacy generally and news media literacy specifically should receive widespread attention in $\mathrm{K}$ through 12 curricula as well as at the undergraduate level. The goal of education should be to create a level playing field for individuals who might wish to be politically and civically engaged, and media education - specifically news media education - is a key component of that goal.

This is an area ripe for future research. This study focused on college students, which is a useful population for understanding where millennials stand broadly, but if we want to know about how news media literacy education affects K-12 students, future studies should focus directly on that population and the potential implications for K-12 education policy. Also, this study, like others in this area (Hobbs et al. 2013), is unable to address the chicken-egg question of 
causal influence. Does knowledge about news media lead to engagement in political life or is this relationship more complex? Though our findings show significant relationships, future research using pre- and post-test designs is needed to demonstrate causation and establish change over time.

Most importantly, this study helps define the most significant components of news media literacy, and future research should further examine the nuanced connections between these particular components (Media Knowledge Structures and Need for Cognition) and desired outcomes. In doing so, scholars and educators must also consider whether lower political trust is an acceptable or desired outcome of news media literacy education. Why does higher literacy relate to lower trust? Scholars also should consider additional measures of news media literacy to further examine these relationships. For now, this study provides empirical evidence of the important relationships between news media literacy education and political engagement, and reminds us that a robust democracy depends on a well-educated citizenry.

\section{References}

Ashley, Seth, Adam Maksl, and Stephanie Craft. 2013. "Developing a News Media Literacy Scale.” Journalism and Mass Communication Educator 68: 7-21.

Ashley, Seth, Mark Poepsel, and Erin Willis. 2010. "Media Literacy and News Credibility: Does Knowledge of Media Ownership Increase Skepticism in News Consumers?" Journal of Media Literacy Education 2: 37-46.

Aufderheide, Patricia, and Charles Firestone. 1993. Media Literacy: A Report Of The National Leadership Conference on Media Literacy. Queenstown, Md.: Aspen Institute.

Baumgartner, Jody and Jonathan S. Morris. 2006. "The Daily Show Effect." American Politics Research 34: 341-367.

Beyerstein, Lindsay. 2014. "Can News Literacy Grow Up?” Columbia Journalism Review. Accessed June 18, 2015. http://www.cjr.org/feature/can_news_literacy_grow_up.php

Campbell, Angus, Gerald Gurin, and Warren E. Miller. 1954. The Voter Decides. Evanston, IL: Row, Peterson.

Chan, Michael. 2014. "Exploring the Contingent Effects of Political Efficacy and Partisan Strength on The Relationship Between Online News Use and Democratic Engagement." International Journal of Communication 8: 1195-1215.

Delli Carpini, Michael X., and Scott Keeter. 1996. What Americans Know About Politics And Why It Matters. New Haven, CT: Yale University Press.

Dewey, Caitlin. 2015. "If You Use Facebook to Get Your News, Please — For the Love of Democracy — Read This First." Washington Post. Accessed June 18, 2015. http://www.washingtonpost.com/news/theintersect/wp/2015/06/03/if-you-use-facebook-to-get-your-news-please-forthe-love-of-democracy-read-this-first/ 
Dudley, Robert L., and Alan R. Gitelson. 2002. "Political Literacy, Civic Education, and Civic Engagement: A Return to Political Socialization?" Applied Developmental Science 6: 175-182.

Epstein, S., R. Pacini, V. Denes-Raj, and H. Heier. 1996. "Individual Differences In Intuitive-Experiential And Analytical-Rational Thinking Styles." Journal of Personality and Social Psychology 71: 390-405.

Eveland, William P., and Dietram A. Scheufele. 2000. "Connecting News Media Use with Gaps in Knowledge and Participation." Political Communication 17: 215-237.

Eveland, William P., Andrew F. Hayes, Dhavan V. Shah, and Nojin Kwak. 2005. "Understanding the Relationship Between Communication and Political Knowledge: A Model Comparison Approach Using Panel Data." Political Communication 22: 423-446.

Fleming, Jennifer. 2014. "Media Literacy, News Literacy, or News Appreciation? A Case Study of the News Literacy Program at Stony Brook University." Journalism and Mass Communication Educator 69: 146-165.

Fleming, Jennifer. 2015. "What do Facts Have to do with it? Exploring Instructional Emphasis in Stony Brook News Literacy Curriculum." Journal of Media Literacy Education 7: 73-92.

Hargittai, Esther. 2010. "Digital Na(t)ives? Variation in Internet Skills and Uses Among Members of the Net Generation." Sociological Inquiry 80: 92113.

Hobbs, Renee. 1998. "The Seven Great Debates In The Media Literacy Movement." Journal of Communication 48: 16-32.

Hobbs, Renee. 2010a. Digital And Media Literacy: A Plan Of Action. Washington, D.C.: The Aspen Institute.

Hobbs, Renee. 2010b. "News Literacy: What Works And What Doesn't." Paper presented at Association for Education in Journalism and Mass Communication conference, Denver, CO.

Hobbs, Renee. 2011. "The State of Media Literacy: A Response to Potter." Journal of Broadcasting and Electronic Media 55: 419-30.

Hobbs, Renee, Katie Donnelly, Jonathan Friesem, and Mary Moen. 2013. "Learning to Engage: How Positive Attitudes About the News, Media Literacy, and Video Production Contribute to Adolescent Civic Engagement." Educational Media International 50: 231-246.

Hoffman, Lindsay H., and Tiffany L. Thomson. 2009. "The Effect of Television Viewing on Adolescents' Civic Participation: Political Efficacy as a Mediating Mechanism." Journal of Broadcasting and Electronic Media 53: 3-21.

Jennings, M. Kent, and Vicki Zeitner. 2003. "Internet Use and Civic Engagement." Public Opinion Quarterly 67: 311-334.

Jeong, Se-Hoon, Hyunyi Cho, and Yoori Hwang. 2012. "Media Literacy Interventions: A Meta-Analytic Review." Journal of Communication 62: $454-472$. 
Jolly, Jihii. 2014. "News Literacy vs. Media Literacy." Columbia Journalism Review. Accessed June 18, 2015. http://www.cjr.org/news_literacy/news_literacy_vs media literac.php

Jordan, Gerald, Megan Pope, Patrick Wallis, and Srividya Iyer. 2014. "The Relationship Between Openness to Experience and Willingness to Engage in Online Political Participation is Influenced by News Consumption." Social Science Computer Review 33: 181-197.

Jung, Nakwon, Yonghwan Kim, and Homero Gil de Zuniga. 2011. "The Mediating Role of Knowledge and Efficacy in the Effects of Communication on Political Participation." Mass Communication and Society 14: 407-430.

Kahne, Joseph, Nam-Jin Lee, Jessica T. Feezell. 2012. "Digital Media Literacy Education and Online Civic and Political Participation." International Journal of Communication 6: 1-24.

Kellner, Douglas, and Jeff Share. 2005. "Toward Critical Media Literacy: Core Concepts, Debates, Organizations, and Policy." Discourse: Studies in the Cultural Politics of Education 26: 369-386.

Lewis, Justin and Sut Jhally. 1998. "The Struggle over Media Literacy." Journal of Communication 48: 109-120.

Maksl, Adam, Seth Ashley, and Stephanie Craft. 2015. "Measuring News Media Literacy." Journal of Media Literacy Education 6: 29-45.

Maksl, Adam, Stephanie Craft, Seth Ashley, and Dean Miller. 2016. "The Usefulness of a News Media Literacy Measure in Evaluating a News Literacy Curriculum." Journalism and Mass Communication Educator. Published online before print May 26, 2016. Accessed February 24, 2017. doi $10.1177 / 1077695816651970$

Masterman, Len. 1997. “A Rationale for Media Education.” In Media Literacy in the Information Age, edited by Robert Kubey, 15-68. New Brunswick, NJ: Transaction.

Mihailidis, Paul. 2014. Media Literacy and the Emerging Citizen: Youth, Engagement and Participation in Digital Culture. New York: Peter Lang.

Mihailidis, Paul, and Benjamin Thevenin. 2013. "Media Literacy as a Core Competency for Engaged Citizenship in Participatory Democracy." American Behavioral Scientist 57: 1611-1622.

Mitchell, Amy, Jeffery Gottfried, and Katerina Matsa. 2015. "Facebook Top Source for Political News Among Millennials." Pew Research Center. Accessed June 18, 2015. http://www.journalism.org/2015/06/01/facebooktop-source-for-political-news-among-millennials/

Mitchell, Amy, Jocelyn Kiley, Jeffrey Gottfried, and Emily Guskin. 2013. "The Role of News on Facebook." Pew Research Center. Accessed June 18, 2015. http://www.journalism.org/2013/10/24/the-role-of-news-onfacebook/

Moeller, Judith, Claes de Vreese, Frank Esser, and Ruth Kunz. 2014. "Pathway to Political Participation: The Influence of Online and Offline News Media on Internal Efficacy and Turnout of First-Time Voters." American Behavioral Scientist 58: 689-700. 
National Association for Media Literacy Education. 2007. "Core Principles of Media Literacy Education in the United States.” Accessed March 20, 2015. http://namle.net/publications/core-principles/

National Association for Media Literacy Education. 2015. "Media Literacy Defined." Accessed March 20, 2015. http://namle.net/publications/\%20media-literacy-definitions/

Pew Research Center. 2013. "What The Public Knows - In Words, Pictures, Maps And Graphs.” Accessed March 20, 2015. http://www.peoplepress.org/2013/09/05/what-the-public-knows-in-words-pictures-maps-andgraphs/

Poindexter, Paula. 2012. Millennials, News, And Social Media: Is News Engagement A Thing Of The Past? New York: Peter Lang.

Potter, W. James. 2004. Theory Of Media Literacy: A Cognitive Approach. Thousand Oaks, Calif.: Sage Publications.

Potter, W. James. 2010. "The State of Media Literacy." Journal of Broadcasting and Electronic Media 54: 675-696.

Toepfl, Florian. 2014. "Four Facets of Critical News Literacy in a NonDemocratic Regime: How Young Russians Navigate their News." European Journal of Communication 29: 69-82.

Verba, S., Schlozman, K., and Brady, H. 1995. Voice And Equality: Civic Voluntarism In American Politics. Cambridge, Mass.: Harvard University Press

Vraga, Emily K., and Melissa Tully. 2015. "Media Literacy Messages and Hostile Media Perceptions: Processing of Nonpartisan Versus Partisan Political Information." Mass Communication and Society 18: 422-448.

Vraga, Emily K., Melissa Tully, and Hernando Rojas. 2009. "Media Literacy Training Reduces Perceptions of Bias." Newspaper Research Journal 30: 68-81.

Vraga, Emily K., Melissa Tully, Heather Akin, and Hernando Rojas. 2012. "Modifying Perceptions of Hostility and Credibility of News Coverage of an Environmental Controversy through Media Literacy." Journalism 13: 942-959.

Vraga, Emily K., Melissa Tully, John E. Kotcher, Anne-Bennett Smithson, and Melissa Broeckelman-Post. 2015. "A Multi-Dimensional Approach to Measuring News Media Literacy." Journal of Media Literacy Education 7: 41-53.

Wallston, Kenneth A., Barbara Strudler Wallston, and Robert DeVellis. 1978. "Development Of The Multidimensional Health Locus Of Control Scales." Health Education and Behavior 6: 160-170.

Zhou, Yushu, and Bruce E. Pinkleton. 2012. "Modeling the Effects of Political Information Source Use and Online Expression on Young Adults' Political Efficacy." Mass Communication and Society 15: 813-830.

Zimmerman, Marc A. 1989. "The Relationship Between Political Efficacy And Citizen Participation: Construct Validation Studies." Journal of Personality Assessment 53: 554-566. 


\section{Appendix A \\ Current Events Knowledge Questions}

What does the gold shaded area on this map represent? All states that currently...

$O$ have a minimum wage above the national minimum

allow same-sex marriage

have the largest Asian populations

$O$ allow the recreational use of marijuana

Which one is a U.S. Senator from New York?

O 1 - Chuck Schumer

O 2 - Bill de Blasio

O 3 - Hillary Clinton

O 4 - Cory Booker

Which best describes the relative numbers of men and women graduating from college with bachelor's degrees in recent years?

More men than women are graduating

More women than men are graduating

About equal numbers of men and women are graduating

What Middle Eastern country is highlighted on this map?

Syria

Saudi Arabia

O Egypt

Turkey

Which of the following shows the trend in the Dow Jones Industrial Average between January 2008 and July 2013?
O 1
O 2
○ 3
○ 4

About what percentage of seats in the U.S. Congress are currently held by women?

O About $20 \%$

About $30 \%$

About $40 \%$

O About 50\%

Who is this?

O Martin O'Malley

O Julian Assange

O Rory McIlroy

O Edward Snowden 
Below are two charts of population pyramids that illustrate the relative size of age groups for a country's population. The chart on the left is the population pyramid for the U.S. What country's population pyramid is shown on the right?

O Japan

O Nigeria

O Israel

O The Netherlands

What is Google Glass?

O A social networking site

O An automobile windshield that displays a car's speed

O A computer that you can wear

O A 3-D home television

In recent years, which of the following Supreme Court justices has most often been the swing vote in closely divided court cases?

O 1 - Antonin Scalia

O 2 - Anthony Kennedy

O 3 - Clarence Thomas

O 4 - Ruth Bader Ginsburg

What kind of policy is the U.S. Federal Reserve primarily responsible for?

O Energy policy

O Monetary policy

Tax Policy

Trade policy

Who is this?

O Marissa Mayer, CEO of Yahoo

Wendy Davis, state senator from Texas

O Lindsey Vonn, professional alpine skier

O Kathleen Sebelius, Secretary of Health and Human Services

What does the term "Common Core" refer to?

The military's code of conduct

O Abdominal exercises

O A newly developed microprocessor

O School curriculum standards for language and math 


\section{Appendix B}

Measures of Political Activity

Did you vote in the 2012 election?

Yes No Not eligible to vote

Did you work as a volunteer for a candidate running for national, state, or local office during the 2012 election?

Yes

No

Did you make a contribution to an individual candidate, a party group, a political action committee, or any other organization that supports candidates in elections during the 2012 election?

Yes

No

Did you contact a government official in the past year?

Yes

No

Did you work informally with others in the community to deal with some issue or problem in the past year?

Yes No

Did you act as a member of or give money to a political organization in the past year?

Yes

No

Did you take part in a protest, march, or demonstration in the past two years?

Yes

No

Did you serve in a voluntary capacity on any local governmental board or council (for example, school or zoning board), or attend meetings of such a board or council regularly in the past two years?

Yes

No 


\section{Appendix C \\ Measures of Political Trust and Political Efficacy}

1. Do you think that quite a few of the people running the government are dishonest, not very many are, or do you think hardly any of them are dishonest?

2. Do you think that people in the government waste a lot of the money we pay in taxes, waste some of it, or don't waste very much of it?

3. How much of the time do you think you can trust the government in Washington to do what is right-just about always, most of the time, or only some of the time?

4. Do you feel that almost all of the people running the government are smart people who usually know what they are doing, or do you think that quite a few of them don't seem to know what they are doing?

5. Would you say the government is pretty much run by a few big interests looking out for themselves or that it is run for the benefit of all the people?

Internal Political Efficacy (scale)

Voting is the only way people like me can have any say about how the government runs things

Sometimes politics and government seem so complicated that a person like me can't really understand what's going on.

External Political Efficacy (scale)

I don't think public officials care much what people like me think.

People like me don't have any say about what the government does.

Interest in Public Affairs (control variable)

Some people seem to think about what's going on in government most of the time whether there's an election going on or not. Others aren't that interested. Would you say you follow what's going on in government most of the time, some of the time, only now and then, or hardly at all? 